J. Dairy Sci. 99:3171-3182

http://dx.doi.org/10.3168/jds.2015-9747

(C) American Dairy Science Association ${ }^{\circledR}, 2016$.

\title{
Prediction of individual milk proteins including free amino acids in bovine milk using mid-infrared spectroscopy and their correlations with milk processing characteristics
}

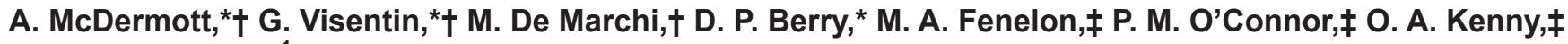 \\ and S. McParland*1 \\ ${ }^{*}$ Teagasc Animal \& Grassland Research and Innovation Centre, Moorepark, Fermoy, Co. Cork, Ireland \\ †Department of Agronomy, Food, Natural Resources, Animals and Environment, University of Padova, Viale dell'Università 16, \\ 35020 Legnaro (PD), Italy \\ $\ddagger$ Teagasc, Food Research Centre, Moorepark, Fermoy, Co. Cork, Ireland
}

\section{ABSTRACT}

The aim of this study was to evaluate the effectiveness of mid-infrared spectroscopy in predicting milk protein and free amino acid (FAA) composition in bovine milk. Milk samples were collected from 7 Irish research herds and represented cows from a range of breeds, parities, and stages of lactation. Mid-infrared spectral data in the range of 900 to $5,000 \mathrm{~cm}^{-1}$ were available for 730 milk samples; gold standard methods were used to quantify individual protein fractions and FAA of these samples with a view to predicting these gold standard protein fractions and FAA levels with available mid-infrared spectroscopy data. Separate prediction equations were developed for each trait using partial least squares regression; accuracy of prediction was assessed using both cross validation on a calibration data set ( $\mathrm{n}=400$ to 591 samples) and external validation on an independent data set $(\mathrm{n}=143$ to 294 samples). The accuracy of prediction in external validation was the same irrespective of whether undertaken on the entire external validation data set or just within the Holstein-Friesian breed. The strongest coefficient of correlation obtained for protein fractions in external validation was $0.74,0.69$, and 0.67 for total casein, total $\beta$-lactoglobulin, and $\beta$-casein, respectively. Total proteins (i.e., total casein, total whey, and total lactoglobulin) were predicted with greater accuracy then their respective component traits; prediction accuracy using the infrared spectrum was superior to prediction using just milk protein concentration. Weak to moderate prediction accuracies were observed for FAA. The

Received April 25, 2015.

Accepted December 8, 2015.

${ }^{1}$ Corresponding author: sinead.mcparland@teagasc.ie greatest coefficient of correlation in both cross validation and external validation was for Gly (0.75), indicating a moderate accuracy of prediction. Overall, the FAA prediction models overpredicted the gold standard values. Near-unity correlations existed between total casein and $\beta$-casein irrespective of whether the traits were based on the gold standard (0.92) or mid-infrared spectroscopy predictions (0.95). Weaker correlations among FAA were observed than the correlations among the protein fractions. Pearson correlations between gold standard protein fractions and the milk processing characteristics of rennet coagulation time, curd firming time, curd firmness, heat coagulating time, $\mathrm{pH}$, and casein micelle size were weak to moderate and ranged from -0.48 (protein and $\mathrm{pH}$ ) to 0.50 (total casein and $\mathrm{a}_{30}$ ). Pearson correlations between gold standard FAA and these milk processing characteristics were also weak to moderate and ranged from -0.60 (Val and $\mathrm{pH})$ to 0.49 (Val and $\mathrm{K}_{20}$ ). Results from this study indicate that mid-infrared spectroscopy has the potential to predict protein fractions and some FAA in milk at a population level.

Key words: mid-infrared spectroscopy, protein fractions, free amino acids, milk quality

\section{INTRODUCTION}

Detailed milk product quality is not considered in the Irish national dairy cow breeding objective, at present, despite its fundamental importance for adding value to the Irish agri-food industry. This is simply due to lack of routine access to data on detailed milk quality parameters, possibly owing to the expense of generating such data using gold standard methods. Consideration of milk quality parameters in national breeding goals is particularly important for exporting countries such as Ireland to consistently achieve a high-quality product suitable for value-added international markets. 
The concentration of protein and the composition of protein fractions in milk influence the production efficiency of cheese, infant milk formula, and both $\mathrm{CN}$ and whey protein supplements. Wedholm et al. (2006) stated that the concentration of $\mathrm{CN}$ in milk protein has a favorable effect on the quantity of protein transferred from milk into cheese curd and high concentrations of $\alpha_{\mathrm{S} 1}-\mathrm{CN}, \beta-\mathrm{CN}$, and $\kappa-\mathrm{CN}$ and of $\beta$-LG $\mathrm{B}$ were found to significantly increase cheese yield. Elofsson et al. (1996) demonstrated a low $\beta$-LG concentration reduces the fouling rate of heating equipment. $\beta$-Lactoglobulin, which is not present in human milk, is a major milk allergen and therefore efforts have been made to reduce the level of this protein in cow milk (Jabed et al., 2012). Therefore, milk protein composition is of increasing importance to the dairy industry due to the expected global demand for cheese (FAOSTAT, 2014). Protein plays an important role in immunity, growth, and development of infants (Lönnerdal, 2003). Therefore, milk protein composition is particularly important for infant formula production (de Wit, 1998) as the composition of bovine milk is different from human milk (Jensen, 1995). Infant formula production is the fastest growing sector in the world dairy market (FAOSTAT, 2014), and the international market for infant milk formula is worth approximately US $\$ 5$ to $\$ 6$ billion annually. Protein composition also affects milk processing characteristics such as the heat coagulating time of bovine milk (Singh, 2004).

Regarding milk processing ability, high free AA (FAA) levels indicate poor quality milk as they arise from protein hydrolysis and are generally in greatest concentration in early and late lactation milk (Davis et al., 1994), when milk quality is poorest (Auldist et al., 1995). Human and bovine milk have different FAA content and composition, with bovine milk generally having a lesser concentration of FAA than human milk (Armstrong and Yates, 1963; Sarwar et al., 1998; Agostoni et al., 2000; Roucher et al., 2013). Therefore, for nutritional reasons, supplementation of infant formula with the required FAA may be of interest in infant formula production. Achieving a milk FAA profile in bovine milk similar to that of human milk through breeding may be an alternative strategy. The FAA profile of milk is therefore of interest to dairy farmers, as milk processors may pay higher prices for milk based on its FAA composition.

Milk compositional traits such as protein fractions have a major influence on milk processing abilityrelated traits such as rennet coagulating time (RCT; Auldist et al., 2004; Ikonen et al., 2004; Wedholm et al., 2006). It is well documented that milk composition and milk coagulation properties are affected by envi- ronmental factors including stage of lactation (Ostersen et al., 1997; Heck et al., 2009). Auldist et al. (1995) documented a stage of lactation effect on both cheese yield and quality. The majority of milk production in Ireland is seasonal (Berry et al., 2006), as most dairy cows calve in spring (Berry et al., 2013). Therefore, it may be of interest to milk processors on how the correlations between milk compositional traits and processing ability characteristics differ in different stages of lactation.

Despite the importance of quantifying individual proteins and FAA in milk, no inexpensive and efficient method of measuring these components in milk is available. Mid-infrared spectroscopy (MIRS) is a technique that studies the interactions between light and matter at wavelengths in the spectral range of 900 to $5,000 \mathrm{~cm}^{-1}$. It is based on the capability of molecules to reflect, transmit, or absorb part of the electromagnetic radiation when exposed to light. According to the Beer-Lambert law (Swinehart, 1962), the quantity of the electromagnetic radiation absorbed is directly proportional to the amount of the absorbent molecule in the sample. Mid-infrared spectroscopy is an efficient method currently used by milk recording organizations worldwide to predict milk fat, protein, and lactose and has recently been used to predict more detailed milk composition traits such as fatty acids (De Marchi et al., 2011; Soyeurt et al., 2011;), coagulation traits (De Marchi et al., 2013), as well as animal-level characteristics such as energy balance (McParland et al., 2011, 2012) and feed efficiency (McParland et al., 2014). Limited studies exist evaluating the effectiveness of MIRS in predicting milk protein fractions (De Marchi et al., 2010; Bonfatti et al., 2011; Rutten et al., 2011). The gold standard method used in both the studies of De Marchi et al. (2010) and Bonfatti et al. (2011) was HPLC; however, Rutten et al. (2011) used capillary zone electrophoresis. In the studies of Bonfatti et al. (2011) and Rutten et al. (2011), the ratio performance deviation ranged from $1.04(\gamma-\mathrm{CN})$ to 2.12 (protein) and from $0.48(\beta-\mathrm{CN})$ to 1.06 (total whey), respectively. Across studies (Bonfatti et al., 2011; Rutten et al., 2011), the coefficient of determination for cross validation ranged from $0.08(\gamma-\mathrm{CN})$ to 0.80 (protein). However, De Marchi et al. (2009) expressed protein fractions as grams per liter, whereas Rutten et al. (2011) expressed them on a protein percentage basis (g/100 g) and Bonfatti et al. (2011) expressed them in both forms. Higher coefficient of determination values were obtained when protein fractions were expressed in grams per liter rather than on a percentage basis.

The aim of this study was to quantify the effectiveness of MIRS to predict individual milk proteins and FAA 
as well as to estimate the association between these MIRS-predicted traits and other phenotypic characteristics of milk including RCT, curd firming time $\left(\mathbf{k}_{\mathbf{2 0}}\right)$, curd firmness $\left(\mathbf{a}_{\mathbf{3 0}}\right)$, heat coagulation time $(\mathbf{H C T})$, and $\mathrm{pH}$. The use of MIRS as a tool to predict detailed milk quality traits is attractive because the mid-infrared spectrum of individual milk samples is available at a negligible cost to routine milk recording.

\section{MATERIALS AND METHODS}

\section{Milk Sample Collection}

Milk samples were obtained from 7 research farms operated by the Teagasc Animal and Grassland Research and Innovation Centre, Moorepark, Fermoy, Co. Cork between August 2013 and August 2014, inclusive. Cows were milked daily at $0700 \mathrm{~h}$ (a.m.) and $1500 \mathrm{~h}$ (p.m.), and milk composition was recorded weekly using a MilkoScan FT6000 (Foss Electronic A/S, Hillerød, Denmark). The resulting spectrum, containing 1,060 transmittance data in the mid-infrared region between 900 and $5,000 \mathrm{~cm}^{-1}$, was stored. Following composition analysis, 505 a.m. and 225 p.m. milk samples were preserved with Broad Spectrum Microtabs II containing $8 \mathrm{mg}$ of Bronopol and $0.3 \mathrm{mg}$ of Natamycin (D\&F Control Systems Inc., Norwood, MA) and stored at $4^{\circ} \mathrm{C}$ for further analysis. Samples were selected to maximize diversity of breed [Holstein Friesian $(\mathrm{n}=454)$, Jersey $(\mathrm{n}=117)$, Norwegian Red $(\mathrm{n}=15)$, and Holstein Friesian, Jersey, and Norwegian Red crossbreds $(\mathrm{n}=144)]$, stage of lactation, milking time (i.e., a.m. or p.m. milking), parity and mid-infrared spectrum and represented 621 animals; animals had a maximum of 3 records each.

\section{Gold Standard Methodologies}

Milk Protein Determination. Total protein was predicted by MIRS and calibrated using the Kjeldahl method. Milk protein fractions were also determined for 557 samples within $48 \mathrm{~h}$ of sample collection. Milk protein fractions were quantified using reverse-phase HPLC. Samples including the Sigma-Aldrich (St. Louis, MO) standards were prepared in denaturing buffer (7 $M$ urea $+20 \mathrm{~m} M$ Bis-Tris propane, $\mathrm{pH} 7.5)$ to which $5 \mu \mathrm{L} / \mathrm{mL}$ of mercaptoethanol was added to give a final protein concentration of approximately $2 \mathrm{mg} /$ $\mathrm{mL}$. The samples were then incubated for $1 \mathrm{~h}$ at room temperature before filtering through a $0.22-\mu \mathrm{m}$ filter. Protein composition was determined by reverse-phase HPLC using an adaptation of the method of Visser et al. (1991). Separation was performed using an Agilent Poroshell 300SB C18 column $(2.1 \mathrm{~mm} \times 75 \mathrm{~mm}$; Agi- lent Technologies UK Ltd., Stockport, UK). The HPLC system consisted of an Agilent 1200 Separation Module with MWD Detector and Agilent Chemstation Software. Gradient elution and peak detection were performed according to Mounsey and O'Kennedy (2009) and Reid et al. (2015). All CN and whey standards were supplied by Sigma-Aldrich.

Total CN was calculated as the sum of $\alpha_{\mathrm{S}^{-}} \mathrm{CN}, \alpha_{\mathrm{S1}^{-}}$ $\mathrm{CN}, \beta-\mathrm{CN}$, and $\kappa-\mathrm{CN}$; total whey was calculated as the sum of $\alpha-\mathrm{LA}, \beta-\mathrm{LG} A$, and $\beta-\mathrm{LG}$ B.

Protein fractions were expressed as grams per liter of milk, but were also expressed as a percentage of total protein or casein by dividing the yield of each protein fraction by the total protein or casein content of the milk sample.

Free Amino Acid Determination. The FAA, Lys, Val, Glu, Gly, Asp, Arg, and Ser were quantified in 715 milk samples using cation exchange HPLC coupled with postcolumn ninhydrin detection as described by Mounier et al. (2007). Seven hundred fifty microliters of each milk sample was deproteinized by mixing with $750 \mu \mathrm{L}$ of $24 \%$ (wt/vol) trichloroacetic acid and left to stand for $10 \mathrm{~min}$. Samples were subsequently centrifuged at 20,817 $\times g$ (Microcentaur; MSE, London, UK) for $10 \mathrm{~min}$ at $4^{\circ} \mathrm{C}$. The resulting supernatants were diluted with $0.2 \mathrm{M}$ sodium citrate buffer ( $\mathrm{pH} 2.2$ ) to give approximately $250 \mathrm{nmol} / \mathrm{mL}$ of each AA residue. Samples were then diluted 1 in 2 with the internal standard, norleucine, to give an end concentration of $125 \mathrm{~nm} / \mathrm{mL}$. Twenty microliters of each sample was then quantified for FAA using a Jeol JLC-500/V AA analyzer (Jeol UK Ltd., Garden City, UK) fitted with a JEOL Na ${ }^{+}$high-performance cation-exchange column.

\section{Determination of Milk Coagulation Properties}

Milk coagulation properties were determined on preserved milk samples within $5 \mathrm{~d}$ of collection, using a Formagraph (Foss Electronic A/S) as described by Visentin et al. (2015). Coagulation properties measured included (1) RCT, defined as the number of minutes taken from rennet addition to the beginning of the coagulation, (2) $\mathrm{k}_{20}$, the time from the gel development to a width of $20 \mathrm{~mm}$ in the graph, and (3) curd firmness measured as the width of the graph after 30 min $\left(a_{30}\right)$ after rennet addition.

\section{Heat Coagulation Time and $\mathrm{pH}$ Determination}

Heat coagulation time was tested within $48 \mathrm{~h}$ of sample collection using the hot oil bath method as described by Davies and White (1966). Heat coagulation time was measured by visual analysis and taken as the 
time when each sample started to coagulate. Samples with a HCT > 30 min were classified as noncoagulating and discarded from the analyses. The $\mathrm{pH}$ of each sample was measured using a Seven compact $\mathrm{pH}$-meter S220 (Mettler Toledo AG, Greifensee, Switzerland) within $24 \mathrm{~h}$ of sample collection.

\section{Data Analysis}

Identification of outlier gold standard values and trait distribution was determined using PROC UNIVARIATE in SAS (SAS Institute Inc., Cary, NC). Traits that did not have a normal distribution were transformed using a natural logarithm transformation. Gold standard values that were $>3$ standard deviations from the mean were considered to be outliers, and up to 3 outliers were removed from the protein fraction analyses, whereas up to 22 outliers were removed from the FAA analyses. Observations for each protein or FAA did not exist for all samples, primarily for logistical reasons (Table 1).

Spectral data were transformed from transmittance to linear absorbance through a logarithmic transformation of the reciprocal of the wavelength values (Soyeurt et al., 2011). Preliminary analyses revealed no improvement in model prediction accuracy following mathematical pre-treatment (Savitzky-Golay first and second derivatives of the log-transformed spectral data); therefore, the prediction models were developed using untreated spectra. Only one spectrometer was used in the present study. Equations were developed to predict each milk quality parameter separately using partial

Table 1. Number of records (n), mean, standard deviation, and coefficient of variation for the studied traits

\begin{tabular}{|c|c|c|c|c|}
\hline Trait & $\mathrm{n}$ & Mean & SD & $\mathrm{CV}$ \\
\hline \multicolumn{5}{|l|}{ Protein, g/L } \\
\hline Total CN & 554 & 35.97 & 7.11 & 19.77 \\
\hline$\alpha_{\mathrm{S} 1}-\mathrm{CN}$ & 557 & 13.92 & 3.18 & 22.84 \\
\hline$\alpha_{\mathrm{S}_{2}}-\mathrm{CN}$ & 555 & 3.62 & 0.97 & 26.90 \\
\hline$\beta-\mathrm{CN}$ & 555 & 12.64 & 2.64 & 20.91 \\
\hline$\kappa-\mathrm{CN}$ & 556 & 5.92 & 1.67 & 28.27 \\
\hline Total whey & 549 & 6.08 & 1.79 & 29.45 \\
\hline$\alpha-\mathrm{LA}$ & 551 & 1.11 & 0.32 & 28.34 \\
\hline Total LG & 552 & 4.97 & 1.65 & 33.20 \\
\hline$\beta-\mathrm{LG}$ A & 557 & 2.55 & 1.26 & 49.42 \\
\hline$\beta$-LG B & 554 & 2.44 & 1.69 & 69.31 \\
\hline \multicolumn{5}{|l|}{ Free $\mathrm{AA}, \mu \mathrm{g} / \mathrm{mL}$} \\
\hline Total free AA & 715 & 64.12 & 22.41 & 34.95 \\
\hline Lys & 686 & 4.52 & 4.26 & 94.35 \\
\hline Val & 625 & 1.67 & 1.43 & 85.73 \\
\hline Glu & 714 & 30.70 & 15.96 & 52.00 \\
\hline Gly & 699 & 7.00 & 5.25 & 74.90 \\
\hline Asp & 595 & 2.62 & 1.63 & 62.45 \\
\hline Arg & 612 & 3.38 & 1.68 & 49.67 \\
\hline Ser & 591 & 1.39 & 0.83 & 59.74 \\
\hline
\end{tabular}

least squares regression (Proc PLS; SAS Institute Inc.). Spectral regions from 926 to $1,580 \mathrm{~cm}^{-1}, 1,717-2,986$ $\mathrm{cm}^{-1}$, and $3,696-3,808 \mathrm{~cm}^{-1}$, were used to develop all prediction models based on the observed loadings for each wavelength.

Accuracy of the prediction equations was determined using external validation whereby $25 \%$ of data were excluded from equation calibration and used as an independent validation data set (VD). This procedure was repeated 4 times, using a different $25 \%$ of the data in the VD each time. Samples were selected for VD to represent similar variation to that present in the gold standard data in the calibration data set (CD) used to develop prediction equations. For each prediction model, the data set was sorted by the trait of interest. The first sample and every fourth sample thereafter were included in the VD for the first iteration; for the second iteration, the second sample and every fourth sample thereafter was chosen for the VD with a similar procedure used for the third and fourth iteration.

Therefore, separate VD and CD were generated for each prediction equation. All records from cows included in the VD were removed from the CD and included only in the VD; therefore, no cow was represented in both the CD and VD in a given iteration.

Criteria used to determine the effectiveness of MIRS predictive models were the coefficient of correlation of cross validation $\left(\mathbf{r}_{\mathrm{c}}\right)$ and external validation $\left(\mathbf{r}_{\mathbf{v}}\right)$, the root mean square error of cross validation (RMSEc) and external validation (RMSEv), the slope (b), which is the linear regression coefficient between predicted values and gold standard values of each trait, the mean bias of prediction, which is the average difference between MIRS-predicted values and gold standard values in external validation, the standard error of the slope, and the bias and the ratio performance deviation (RPD), which is the ratio of the standard error in prediction to the standard deviation of each trait. Four validation data sets were created and then appended onto each other and the $r_{c}, r_{v}$, RMSE, b (SE), and bias (SE) was calculated based on all 4 iterations of combined. The average number of factors (\#L) used to build the prediction equations was the average number from all 4 iterations rounded to the nearest whole number. Validation was also performed within just the Holstein-Friesian breed (i.e., the predominant breed) as well as across breeds. Furthermore, protein fractions were also predicted in the external validation using just the total milk protein concentration and compared with prediction accuracy using the MIRS.

Pearson correlations among the gold standard and among the MIRS-predicted values of protein fractions and FAA were estimated. Pearson correlations between 
gold standard and MIRS-predicted FAA with RCT, $\mathrm{k}_{20}$, $\mathrm{a}_{30}, \mathrm{HCT}$, and $\mathrm{pH}$ were also estimated.

\section{RESULTS}

The total data set consisted of 730 samples; 584 milk samples were from spring-calving cows fed a predominantly grazed grass-based diet and the remaining 146 samples were from autumn-calving cows fed a TMR diet. Milk samples represented different stages of lactation and ranged from 5 to $375 \mathrm{~d}$ in milk; first to eleventh parity cows were represented.

\section{Descriptive Statistics}

Mean gold standard values of all milk traits are summarized in Table 1. Mean values of $\alpha_{\mathrm{S}_{1}} \mathrm{CN}(13.92 \mathrm{~g} / \mathrm{L})$, $\alpha_{\mathrm{S} 2}-\mathrm{CN}(3.62 \mathrm{~g} / \mathrm{L}), \beta-\mathrm{CN}(12.64 \mathrm{~g} / \mathrm{L})$, and $\kappa-\mathrm{CN}(5.92$ $\mathrm{g} / \mathrm{L})$ in the present study were approximately in the ratio 3:1:3:1. Large differences were observed in the coefficient of variation across traits. The coefficient of variation for protein fractions ranged from $20 \%$ (total $\mathrm{CN})$ to $69 \%$ ( $\beta$-LG B).

The FAA present at the greatest concentration was Glu (mean $=30.70 \mu \mathrm{g} / \mathrm{mL}$ ) but exhibited a large variability (SD of $15.96 \mu \mathrm{g} / \mathrm{mL}$ ), whereas Ser was present at the lowest concentration $($ mean $=1.39 \mu \mathrm{g} / \mathrm{mL})$. The coefficient of variation was generally large for all FAA, with a wide range from $35 \%$ (total FAA) to $94 \%$ (Lys).

The lactation profile of (gold standard) total FAA (Figure 1) indicated that the concentration of total FAA was greatest in early and late lactation. Protein concentration decreased in early lactation and increased linearly across lactation thereafter (Figure 2).

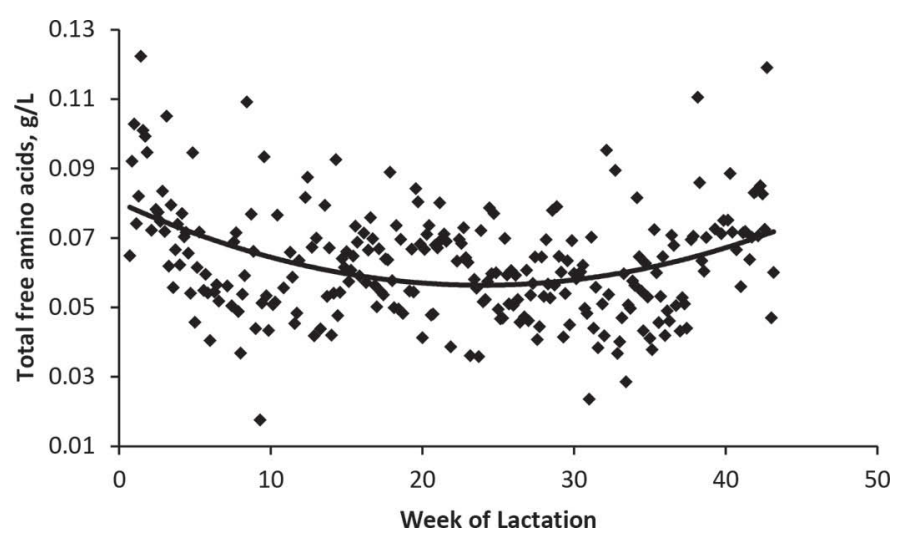

Figure 1. Trend in total free AA (i.e., the sum of gold standard Lys, Val, Glu, Gly, Asp, Arg, Ser) across lactation.

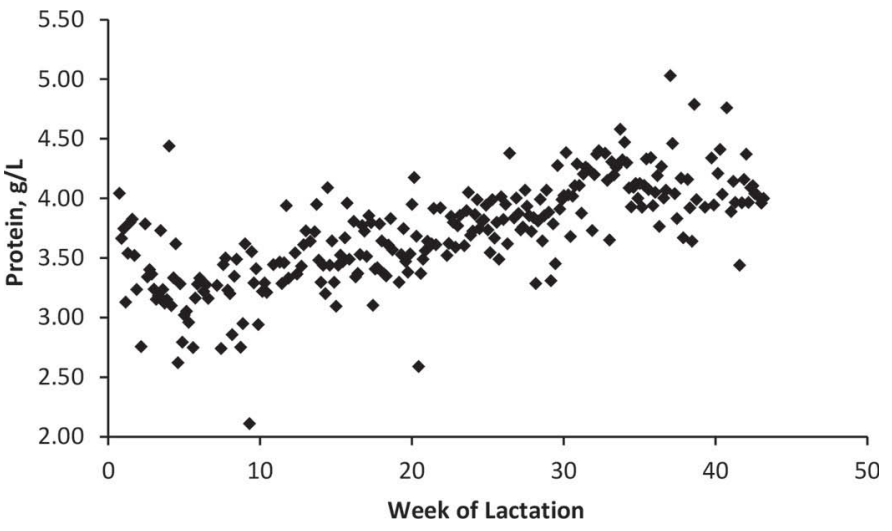

Figure 2. Trend in protein concentration across lactation.

\section{Protein Prediction Accuracy}

Prediction accuracies achieved for cross validation and external validation are summarized in Table 2 . The mean bias in prediction of protein fractions was not different from zero $(P>0.05)$. The number of factors included in the partial least squares prediction model varied from 4 (total $\mathrm{CN}, \alpha_{\mathrm{S} 1}-\mathrm{CN}, \beta-\mathrm{CN}$, and $\beta-\mathrm{LG} \mathrm{B}$ ) to 16 ( $\beta$-LG A). The $r_{c}$ between gold standard and MIRSpredicted protein fractions ranged from 0.43 ( $\beta$-LG A) to 0.76 (total $\mathrm{LG}$ ), and the greatest $\mathrm{r}_{\mathrm{v}}$ values obtained for protein fractions were $0.67,0.69$, and 0.74 for $\beta-\mathrm{CN}$, total $\beta$-LG, and total $\mathrm{CN}$, respectively. Total $\mathrm{CN}$ also had the greatest RPD (1.49). The slope between the gold standard and MIRS-predicted values for protein fractions ranged from 0.76 ( $\beta-\mathrm{LG} \mathrm{B})$ to $0.99(\kappa-\mathrm{CN}$ and $\beta-\mathrm{CN})$. The average difference in $\mathrm{r}_{\mathrm{v}}$ when undertaken across all breeds or within just the Holstein-Friesians (Supplemental Table S1; http://dx.doi.org/10.3168/ jds.2015-9747) varied from $-0.08(\mathrm{Arg})$ to $0.06\left(\alpha_{\mathrm{S} 1^{-}}\right.$ $\mathrm{CN})$.

The $\mathrm{r}_{\mathrm{v}}$ for the different proteins predicted from just protein content was on average 0.18 less than prediction of the same traits using MIRS. Expressing protein fractions as a percentage of total protein, accuracy of prediction was poorer than when proteins were expressed as grams per deciliter of milk (results not shown); the difference between $r_{v}$ for traits when expressed as grams per liter of milk compared with when expressed as a percentage of protein ranged from $0.01(\kappa-\mathrm{CN})$ to $0.42(\alpha-\mathrm{LA})$.

\section{Prediction Accuracy of Free Amino Acids}

Accuracy of the developed equations to predict FAA are summarized in Table 2. The number of factors included in the prediction model ranged from 9 (Ser and 
Table 2. Number of records (n), average number of factors (\#L; rounded to the nearest whole number), root mean square error (RMSE), correlation coefficient between gold standard and predicted values in cross validation $\left(\mathrm{r}_{\mathrm{c}}\right)$ and external validation $\left(\mathrm{r}_{\mathrm{v}}\right)$, bias (SE in parentheses), slope (b: SE in parentheses), and ratio performance deviation (RPD) tested using the split sample cross validation and external validation

\begin{tabular}{|c|c|c|c|c|c|c|c|c|c|}
\hline Trait & $\mathrm{n}$ & \multicolumn{3}{|c|}{ Cross validation } & \multicolumn{5}{|c|}{ External validation } \\
\hline$\alpha_{\mathrm{S} 1}-\mathrm{CN}$ & 557 & 4 & 2.16 & 0.70 & $0.0057(2.23)$ & $0.97(0.05)$ & 1.26 & 0.66 & 1.35 \\
\hline$\alpha_{\mathrm{S} 2}-\mathrm{CN}$ & 555 & 5 & 0.78 & 0.60 & $0.0072(0.80)$ & $0.90(0.06)$ & 1.99 & 0.66 & 1.22 \\
\hline$\beta-\mathrm{CN}$ & 555 & 4 & 1.92 & 0.69 & $0.0008(1.99)$ & $0.99(0.05)$ & 2.37 & 0.67 & 1.33 \\
\hline$\alpha-\mathrm{LA}$ & 551 & 8 & 0.26 & 0.58 & $0.0012(0.26)$ & $0.88(0.06)$ & 0.26 & 0.54 & 1.17 \\
\hline Total LG & 552 & 14 & 1.01 & 0.76 & $0.0015(1.06)$ & $0.87(0.04)$ & 1.20 & 0.69 & 1.38 \\
\hline$\beta$-LG A & 557 & 16 & 1.14 & 0.43 & $0.0003(1.14)$ & $0.94(0.09)$ & 1.16 & 0.39 & 1.09 \\
\hline$\beta-\mathrm{LG} B$ & 554 & 4 & 1.29 & 0.65 & $0.0016(1.50)$ & $0.76(0.06)$ & 1.39 & 0.44 & 1.15 \\
\hline \multicolumn{10}{|l|}{ Free AA } \\
\hline Total free AA & 715 & 12 & 16.29 & 0.69 & $-0.0487(17.87)$ & $0.88(0.04)$ & 17.79 & 0.61 & 1.26 \\
\hline Lys $^{1}$ & 686 & 14 & 0.56 & 0.69 & $-0.6910(3.30)$ & $0.89(0.04)$ & 3.35 & 0.55 & 1.27 \\
\hline Ser $^{1}$ & 591 & 9 & 0.48 & 0.51 & $-0.1460(0.79)$ & $0.67(0.07)$ & 1.22 & 0.42 & 1.07 \\
\hline
\end{tabular}

${ }^{1}$ Traits were log-transformed before analysis.

Arg) to 15 (Gly). Moderate prediction accuracy of FAA were achieved, particularly for Gly, Lys, and Glu, with an $\mathrm{r}_{\mathrm{c}}$ and $\mathrm{r}_{\mathrm{v}}$ of 0.75 and 0.75 , respectively, for Gly and an $\mathrm{r}_{\mathrm{c}}$ of 0.68 and an $\mathrm{r}_{\mathrm{v}}$ of 0.59 , respectively, for Glu; Gly also had the greatest RPD (1.38). Arginine had the lowest $r_{v}(0.26)$. The slope between the gold standard and MIRS-predicted values ranged from 0.67 (Ser) to 0.92 (Asp). The FAA were on average overpredicted $(P$ $<0.05)$.

\section{Phenotypic Correlations}

Pearson correlations among the protein fractions are summarized in Table 3. Correlations among the gold standard proteins and among the MIRS-predicted protein fractions were all different $(P<0.05)$ from zero. The correlations between gold standard total $\mathrm{CN}$ and gold standard casein fractions ranged from $0.67\left(\alpha_{\mathrm{S}^{-}}\right.$ $\mathrm{CN})$ to $0.92\left(\alpha_{\mathrm{S}^{-}} \mathrm{CN}\right.$ and $\left.\beta-\mathrm{CN}\right)$ and were similar to correlations between the MIRS-predicted total CN and the MIRS-predicted components of CN. However, the correlation between the gold standard values of $\alpha_{\mathrm{S} 1}-\mathrm{CN}$ and $\alpha_{\mathrm{S}_{2}} \mathrm{CN}(0.53)$ was weaker than the respective correlation between the MIRS-predicted values (0.85).

The correlation between total whey and total LG was 0.99 (gold standard values) and 0.94 (MIRS-predicted values). Similarly, the correlation between the gold standard $\alpha$-LA and total LG (0.47) was similar to the respective correlation between their MIRS-predicted values (0.48), whereas the correlations between the gold standard $\beta-\mathrm{LG} \mathrm{A}$ and $\beta-\mathrm{CN}(0.36)$ and their corresponding MIRS-predicted values (0.79) differed.

Pearson correlations among gold standard FAA and among MIRS-predicted FAA are in Table 4. In general, the correlations among the gold standard FAA and the respective correlations among the MIRS-predicted FAA were in less agreement than the correlations among the gold standard or the MIRS-predicted protein fractions.

Pearson correlations among protein-related traits (i.e., MIRS-predicted protein, MIRS-predicted casein, gold standard protein fractions) and milk processing characteristics (i.e., $\mathrm{RCT}, \mathrm{k}_{20}, \mathrm{a}_{30}, \mathrm{HCT}$, and $\mathrm{pH}$ ) in early $(\mathrm{DIM}<60)$ and late $(\mathrm{DIM}>180)$ lactation are in Table 5; all correlations were generally weak to moderate. Rennet coagulating time was positively associated with MIRS-predicted protein in early lactation $(\mathrm{r}=0.19)$, but was negatively correlated with MIRS-predicted protein in late lactation $(\mathrm{r}=-0.11)$, corresponding with the increase in protein concentration across lactation (Figure 2). In early lactation, RCT was negatively associated with MIRS-predicted casein $(-0.21)$. Curd firming time was negatively correlated with the protein-related traits in both early and late lactation. The opposite was true for $\mathrm{a}_{30}$, which was generally positively correlated with the protein-related traits in early and late lactation. Native $\mathrm{pH}$ was negatively correlated with gold standard protein fractions in early lactation, but was both negatively and positively 


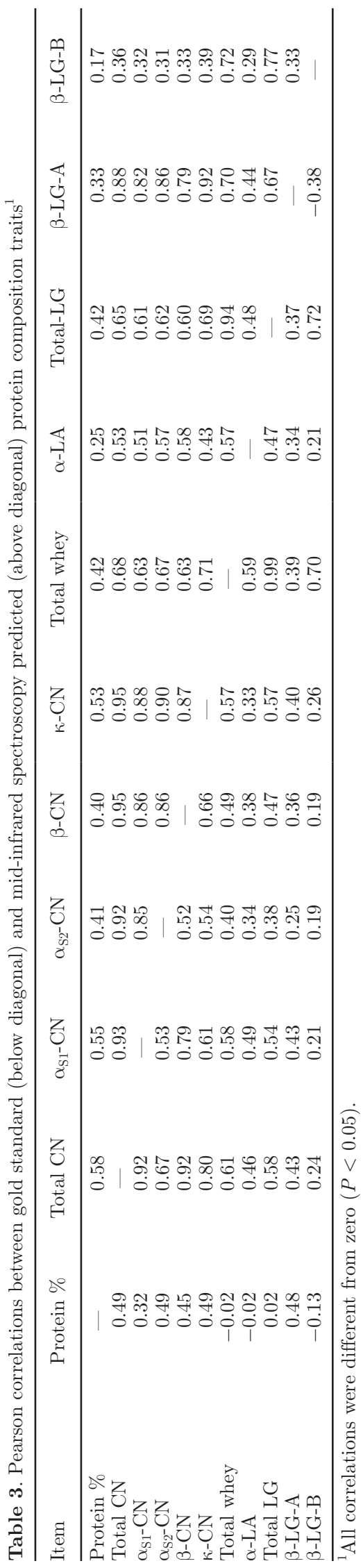

correlated with gold standard protein fractions in late lactation. The correlations among HCT and $\beta-\mathrm{LG}$ in early and late lactation were -0.17 and 0.22 , respectively. The Pearson correlations between HCT and $\kappa-\mathrm{CN}$ in both early and late lactation were not different from zero $(\mathrm{r}=-0.05$ and $\mathrm{r}=0.08$, respectively).

Correlations between gold standard FAA and milk processing characteristics in early $(\mathrm{DIM}<60)$ and late $($ DIM $>180)$ lactation are in Table 6. Correlations were strongest among gold standard FAA and the milk processing characteristics in early lactation. Similar to the correlations with the gold standard FAA, RCT was positively associated with MIRS-predicted FAA in late lactation (Supplemental Table S2; http://dx.doi. org/10.3168/jds.2015-9747). However, $\mathrm{a}_{30}$ was positively associated with MIRS-predicted FAA in early lactation but was negatively associated with MIRSpredicted FAA in late lactation (Supplemental Table S2; http://dx.doi.org/10.3168/jds.2015-9747). In early lactation, $\mathrm{pH}$ was negatively correlated with all gold standard FAA.

\section{DISCUSSION}

The objective of the present study was to demonstrate the ability of MIRS to predict milk quality traits, including 7 individual proteins and 7 FAA. Predictions of these traits by MIRS could be of benefit to the dairy industry because MIRS is a low-cost and efficient method for acquiring phenotypic information on milk quality using infrastructure and logistics for the acquisition of milk samples that already exists.

Limited studies exist evaluating the effectiveness of MIRS in predicting milk protein composition (De Marchi et al., 2010; Bonfatti et al., 2011; Rutten et al., 2011), and no studies have evaluated the ability of the MIRS to predict FAA. Furthermore, comparison with other studies of MIRS-prediction accuracy for protein fractions is difficult due to differences in the dairy production system as well as methods of determining protein fractions used (i.e., different gold standard analyses, experimental design, different breeds, stages of lactations, parities, diets and milking times). For example, the level of $\mathrm{CP}$ in the diet affects the milk protein profile (Reid et al., 2015); animals in the present study were on a predominately grass-based diet. To our knowledge, this is the first study to use data from a mainly grazed grass-based production system to develop equations to predict protein composition and FAA from milk MIRS.

Caseins constitute approximately $80 \%$ of milk protein and consist of $\alpha_{\mathrm{S} 1}-\mathrm{CN}, \alpha_{\mathrm{S} 2}-\mathrm{CN}, \beta-\mathrm{CN}$, and $\kappa-\mathrm{CN}$ fractions, typically in the ratio 3:1:3:1 (Farrell et al., 2004). Mean values of the respective caseins in the pres- 
Table 4. Pearson correlations between gold standard (below diagonal) and mid-infrared spectroscopy predicted (above diagonal) free $\mathrm{AA}^{1}$

\begin{tabular}{lrlllrrr}
\hline Trait & Lys & Val & Glu & Gly & Asp & Arg & Ser \\
\hline Lys & - & 0.69 & -0.23 & 0.05 & -0.18 & 0.69 & 0.31 \\
Val & 0.57 & - & 0.01 & 0.26 & 0.06 & 0.67 & 0.36 \\
Glu & -0.10 & 0.20 & - & 0.38 & 0.70 & -0.29 & 0.10 \\
Gly & 0.07 & 0.31 & 0.35 & - & 0.40 & -0.10 & 0.30 \\
Asp & -0.01 & 0.15 & 0.70 & 0.33 & - & -0.40 & -0.10 \\
Arg & 0.53 & 0.58 & 0.03 & 0.08 & -0.06 & - & 0.39 \\
Ser & 0.19 & 0.35 & 0.34 & 0.43 & 0.14 & 0.43 & - \\
\hline
\end{tabular}

${ }^{1}$ Traits were log-transformed before analysis. Correlations $\leq|0.07|$ were not different from zero $(P>0.05)$.

ent study were consistent with this ratio. Mean values of 1.11 and $4.97 \mathrm{~g} / \mathrm{L}$ for both the gold standard and MIRS-predicted $\alpha$-LA and total LG were in the ratio of 1:3, consistent with values documented by Farrell et al. (2004). Similarly, the ratio of total CN to total whey was 6:1 irrespective of whether it was calculated using the gold standard or MIRS-predicted values. Multiple sampling dates, as well as variability attributed to the numerous research farms, breeds, parities, and milking times used to maximize the variation in the sample populations, are likely contributing to the greater coefficient of variation in protein fractions compared with other studies (De Marchi et al., 2010).

Glutamic acid was the FAA present in the greatest concentration in the milk. This conclusion was consistent with previous studies by Sarwar et al. (1998), Lindmark-Mansson et al. (2003), and Roucher et al. (2013), who also documented Glu to be one of the most abundant FAA in bovine milk. The FAA Asp, Arg, and Ser were present in low concentrations in the present study.

The lactation profile of (gold standard) total FAA (Figure 1) indicated that the greatest concentration of FAA was during early and late lactation. This was similar to a finding by Ghadimi and Pecora (1963), who also documented variation in the concentration of FAA at different stages of lactation, with the greatest concentration of FAA present in the colostrum, and the least concentration in transitional milk.

\section{Milk MIRS Prediction Equations}

Prediction of Protein Fractions. The $r_{c}$ and $r_{v}$ of total proteins (i.e., total $\mathrm{CN}$, total whey, and total $\beta-\mathrm{LG})$ were predicted with greater accuracy than their components, which was probably attributed in part to their greater concentration in the milk. The ability to predict components in greater concentration in the milk corroborates the conclusion of Soyeurt et al. (2006, 2011) and Rutten et al. (2009), who all attempted to predict milk fatty acid content using MIRS. Accuracy of prediction of protein fractions overall in the present study were consistent with those documented in other publications previously (De Marchi et al., 2010; Bonfatti et al., 2011; Rutten et al., 2011). Differences among studies could be due to differences in the gold standard methods used. The HPLC was used in this present study as well as in both the studies of De Marchi et al. (2010) and Bonfatti et al. (2011), whereas Rutten et al. (2011) used capillary zone electrophoresis. The traits predicted with the poorest accuracy were $\beta$-LG A and $\beta$-LG B $\left(r_{v}=0.39\right.$ and $\left.r_{v}=0.44\right)$. This may be because the quantity of $\beta-\mathrm{LG} A$ and $\beta-\mathrm{LG} B$ are directly related to the milk protein variants of the cow; if cows are AA the content of $\beta-\mathrm{LG} \mathrm{B}$ is 0 and if cows are $\mathrm{BB}$ the content of $\beta-\mathrm{LG}$ A is 0 ( $\mathrm{Ng}-\mathrm{K}$ wai-Hang and Kim, 1996).

A high RPD is advantageous; an RPD greater than 2 indicates the generated prediction could be used for analytical purposes (Williams, 2007). No RPD value greater than 2 was achieved, however, in the present study. All protein fractions had an RPD between 1 and 2 in the present study, and this finding is consistent with a previous study on milk protein fractions (Bonfatti et al., 2011). According to Williams (2007), a slope of the gold standard values on the MIRS-predicted values of a trait that deviates greatly from 1 (e.g., less than 0.85 and 1.15 or greater) will result in an unstable calibration, whereas a prediction equation with a slope between 0.95 and 1.05 will be more stable. The prediction models for 4 protein fractions (total $\mathrm{CN}, \alpha_{\mathrm{S1}^{-}} \mathrm{CN}$, $\beta-\mathrm{CN}$, and $\kappa-\mathrm{CN}$ ) had slopes between 0.95 and 1.00 in the present study. Protein fractions were, however, on average underpredicted. This could result in farmers being underpaid should a milk payment system on protein fractions be implemented.

A poorer accuracy of prediction was obtained when protein fractions were expressed as a percentage of MIRS-predicted protein in milk; this was consistent with results from previous studies by Bonfatti et al. (2011) on protein fractions and by Soyeurt et al. (2006) on fatty acid content. The poorer accuracy of prediction 
when protein fractions were expressed as a percentage could be explained by a variation in the protein fractions present in different milk samples. For example, 2 milk samples could have the same concentration of protein in the milk, but be made up of different protein fractions. Another possible explanation for poorer accuracy of prediction is that the protein content of milk was actually predicted and not the actual protein composition. Protein content and protein composition are highly correlated (expressed as g/L). Nonetheless, exploiting the infrared spectrum in the prediction of milk protein composition generated superior prediction accuracy than when protein composition was predicted solely based on milk protein content suggest that the spectrum is in fact providing additional information in the prediction process.

Prediction of Free Amino Acids. The present study is the first attempt to predict FAA in milk from MIRS. The moderate prediction accuracies for FAA achieved in the present study may be due to the low concentration of FAA present in the milk samples. The optimum number of factors included in the partial least squares prediction model for FAA was similar to previous studies (De Marchi et al., 2010; Soyeurt et al., 2011) for the prediction of CN fractions and fatty acid composition. However, FAA required a greater number of factors than for $\mathrm{CN}$ fraction prediction in the present study.

Glutamic acid, which was predicted with moderate accuracy from MIRS, may be important for infant formula production as the sum of Glu and Gln represents $50 \%$ of the total FAA in human milk (Agostoni et al., 2000). The prediction ability for all FAA was too poor for industrial use. The prediction models for all FAA had slopes of the gold standard values on the MIRSpredicted values between 0.85 and 1 , with the exception of Val (0.76) and Ser (0.67), which had slopes of the gold standard values on the MIRS-predicted values of $<0.85$ and therefore may have unstable calibrations (Williams, 2007).

Because protein and FAA are correlated, the MIRS could be indirectly predicting the FAA by predicting the protein content of the milk.

\section{Phenotypic Correlations}

The correlations among the gold standard traits were comparable to the correlations among the corresponding MIRS-predicted traits for the majority of protein fraction traits. This could be due to the moderately accurate predictions, which yielded MIRS-predicted protein fraction values similar to gold standard protein fraction values. The correlation between gold standard $\beta$-LG A and gold standard $\beta$-LG B $(-0.38)$ was not 
in agreement with the correlation between the MIRSpredicted $\beta$-LG $\mathrm{A}$ and the MIRS-predicted $\beta$-LG-B (0.33), as these protein fractions $\beta-\mathrm{LG} \mathrm{A}\left(\mathrm{r}_{\mathrm{v}}=0.39\right)$ and $\beta-\mathrm{LG} B\left(\mathrm{r}_{\mathrm{v}}=0.44\right)$ were poorly predicted from MIRS. The poor prediction of $\beta-\mathrm{LG} A$ and $\beta-\mathrm{LG} \mathrm{B}$ may also contribute to the large difference in the correlations between the gold standard and MIRS-predicted values of these 2 traits with total $\mathrm{CN}$.

Overall, the correlations among the gold standard FAA and the respective correlations among the MIRSpredicted FAA were in less agreement than the correlations among the gold standard and the MIRS-predicted protein fractions; this may be due to poorer accuracy of prediction for FAA.

Previous studies have shown that $\mathrm{RCT}, \mathrm{k}_{20}$, and $\mathrm{pH}$ are all positively correlated and these traits are all negatively correlated with both $\mathrm{a}_{30}$ and HCT (Ikonen et al., 2004; Cassandro et al., 2008; Visentin et al., 2015). Therefore, if RCT has a positive correlation with protein; $\mathrm{k}_{20}$ and $\mathrm{pH}$ should also have positive correlations with protein and both $\mathrm{a}_{30}$ and HCT should be negatively correlated with protein. This study estimated RCT was positively correlated with MIRS-predicted protein and the majority of gold standard protein fractions in early lactation, but in late lactation RCT was negatively correlated with MIRS-predicted protein and gold standard protein fractions. The correlations between RCT, MIRS-predicted protein, and gold standard protein fractions could be explained by the increase in protein content throughout lactation (Figure 2) because as protein content increases, RCT decreases (Visentin et al., 2015) and also the FAA concentration decreases. Throughout lactation, $\mathrm{k}_{20}$ had negative associations with protein-related traits but had positive associations with the majority of gold standard FAA; this could be due to protein hydrolysis, which releases
FAA into the milk. The negative associations of $k_{20}$ with protein-related traits and the positive associations of $k_{20}$ with the majority of gold standard FAA were also in accordance with the positive correlation among RCT and $\mathrm{k}_{20}$. The RCT was negatively correlated with $\mathrm{a}_{30}$; therefore, the positive correlations between $\mathrm{a}_{30}$ and protein-related traits in both early and late lactations and the negative associations with gold standard FAA in mid lactation were expected. Negative correlations were demonstrated between $\mathrm{pH}$ and both MIRSpredicted $\mathrm{CN}$ and gold standard protein fractions in early lactation, but both negative and positive correlations were demonstrated between $\mathrm{pH}$ and these traits in late lactation. These correlations may be explained by Vasbinder and De Kruif (2003), who showed that a small change in $\mathrm{pH}$ had a large effect on whey protein denaturation and gelation properties of milk. Milk proteins, in particular $\beta-\mathrm{LG}$ and $\kappa-\mathrm{CN}$, are known to have an effect on milk processing characteristics, such as HCT (Singh, 2004). However, no strong correlations were demonstrated between these proteins and milk processing characteristics in this present study.

\section{CONCLUSIONS}

Findings from this study indicate that MIRS is useful to routinely and efficiently measure milk quality traits such as protein fractions and some FAA at a population level. Prediction of these traits by MIRS could play an important role in selective breeding and therefore be of benefit to the dairy and breeding industry worldwide, allowing for the more accurate selection of milk for human consumption, infant milk formula, and cheese production. Further research is required to quantify genetic correlations between protein fractions and FAA and to estimate the genetic variance of these traits, which will

Table 6. Pearson correlations ${ }^{1}$ between gold standard free AA (FAA) and rennet coagulation time (RCT), curd-firming time ( $\left.\mathrm{k}_{20}\right)$, curd firmness $\left(\mathrm{a}_{30}\right)$, heat coagulation time $(\mathrm{HCT})$, and $\mathrm{pH}$ across 2 stages of lactation

\begin{tabular}{|c|c|c|c|c|c|c|c|c|}
\hline Item & Lys & Val & Glu & Gly & Asp & Arg & Ser & Total FAA \\
\hline \multicolumn{9}{|c|}{ Early lactation } \\
\hline RCT & 0.14 & -0.02 & $0.19^{*}$ & -0.05 & 0.04 & 0.16 & $-0.10^{*}$ & 0.05 \\
\hline HCT & -0.12 & -0.01 & 0.06 & -0.35 & -0.06 & 0.11 & -0.10 & 0.02 \\
\hline $\mathrm{pH}$ & $-0.48^{*}$ & $-0.60^{*}$ & $-0.33^{*}$ & $-0.52^{*}$ & $-0.32^{*}$ & $-0.30^{*}$ & $-0.38^{*}$ & $-0.51^{*}$ \\
\hline \multicolumn{9}{|c|}{ Late lactation } \\
\hline $\mathrm{a}_{30}$ & 0.06 & -0.01 & -0.34 & -0.03 & -0.11 & -0.09 & -0.26 & -0.22 \\
\hline $\mathrm{HCT}$ & -0.23 & 0.03 & 0.08 & -0.04 & -0.13 & 0.02 & 0.08 & 0.01 \\
\hline $\mathrm{pH}$ & $-0.09^{*}$ & $0.09^{*}$ & $0.09 *$ & $-0.06^{*}$ & $-0.01^{*}$ & $0.05^{*}$ & $0.27^{*}$ & $-0.02^{*}$ \\
\hline
\end{tabular}

${ }^{1}$ Correlations $\leq|0.18|$ were not different from zero $(P>0.05)$.

*Correlations are significantly different to each other in early and late lactation $(P<0.01)$. 
indicate the usefulness of the developed MIRS models for practical animal breeding purposes.

\section{ACKNOWLEDGMENTS}

Funding for this work was received from the Irish Department of Agriculture, Food and the Marine, Research Stimulus Fund project 11/SF/311, Breed Quality. The authors gratefully acknowledge the laboratory assistance of Bernard Corrigan (Teagasc, Food Research Centre, Moorepark, Fermoy, Co. Cork, Ireland).

\section{REFERENCES}

Agostoni, C., B. Carratu, C. Boniglia, E. Riva, and E. Sanzini. 2000. Free amino acid content in standard infant formulas: Comparison with human milk. J. Am. Coll. Nutr. 19:434-438.

Armstrong, M. D., and K. N. Yates. 1963. Free amino acids in milk. Proc. Soc. Exp. Biol. Med. 113:680-683.

Auldist, M. J., K. A. Johnston, N. J. White, W. P. Fitzsimons, and M. J. Boland. 2004. A comparison of the composition, coagulation characteristics and cheesemaking capacity of milk from Friesian and Jersey dairy cows. J. Dairy Res. 71:51-57.

Auldist, M. P., S. Coats, G. L. Rogers, and G. H. McDowell. 1995. Changes in composition of milk from healthy and mastitic cows during the lactation cycle. Aust. J. Exp. Agric. 35:427-436.

Berry, D. P., J. F. Kearney, K. Twomey, and R. D. Evans. 2013. Genetics of reproductive performance in seasonal calving dairy cattle production systems. Ir. J. Agric. Food Res. 52:1-16.

Berry, D. P., B. O'Brien, E. J. O'Callaghan, K. O. Sullivan, and W. J. Meaney. 2006. Temporal trends in bulk tank somatic cell count and total bacterial count in Irish dairy herds during the past decade. J. Dairy Sci. 89:4083-4093.

Bonfatti, V., G. Di Martino, and P. Carnier. 2011. Effectiveness of mid-infrared spectroscopy for the prediction of detailed protein composition and contents of protein genetic variants of individual milk of Simmental cows. J. Dairy Sci. 94:5776-5785.

Cassandro, M., A. Comin, M. Ojala, R. Dal Zotto, M. De Marchi, L. Gallo, P. Carnier, and G. Bittante. 2008. Genetic parameters of milk coagulation properties and their relationships with milk yield and quality traits in Italian Holstein cows. J. Dairy Sci. 91:371376 .

Davies, D. T., and J. C. D. White. 1966. The stability of milk protein to heat: I. Subjective measurement of heat stability of milk. J. Dairy Res. 33:67-81.

Davis, T. A., H. V. Nguyen, R. Garcia-Bravo, M. L. Fiorotto, E. M. Jackson, and P. J. Reids. 1994. Amino acid composition of the milk of some mammalian species changes with stage of lactation. Br. J. Nutr. 72:845-853.

De Marchi, M., V. Bonfatti, A. Cecchinato, G. Di Martino, and P. Carnier. 2010. Prediction of protein composition of individual cow milk using mid-infrared spectroscopy. Ital. J. Anim. Sci. 8(2s):399 401.

De Marchi, M., M. Penasa, A. Cecchinato, M. Mele, P. Secchiari, and G. Bittante. 2011. Effectiveness of mid-infrared spectroscopy to predict fatty acid composition of Brown Swiss bovine milk. Animal 5:1653-1658.

De Marchi, M., V. Toffanin, M. Cassandro, and M. Penasa. 2013. Prediction of coagulating and non-coagulating milk samples using mid-infrared spectroscopy. J. Dairy Sci. 96:4707-4715.

de Wit, J. N. 1998. Nutritional and functional characteristics of whey proteins in food products. J. Dairy Sci. 81:597-608.

Elofsson, U. M., M. A. Paulsson, P. Sellers, and T. Arnebrant. 1996. Adsorption during heat treatment related to the thermal unfolding/aggregation of $\beta$-lactoglobulins A and B. J. Colloid Interface Sci. 183:408-415.
FAOSTAT. 2014. Metadata/production. Accessed Sep. 11, 2014. http://faostat3.fao.org/faostat-gateway/go/to/download/Q/*/E.

Farrell, H. M. Jr., R. Jimenez-Flores, G. T. Bleck, E. M. Brown, J. E. Butler, L. K. Creamer, C. L. Hicks, C. M. Hollar, K. F. Ng-KwaiHang, and H. E. Swalsgood. 2004. Nomenclature of the proteins of cows' milk — Sixth revision. J. Dairy Sci. 87:1641-1674.

Ghadimi, H., and P. Pecora. 1963. Free amino acids of different kinds of milk. Am. J. Clin. Nutr. 13:75-81.

Heck, J. M. L., H. J. F. Van Valenberg, J. Dijkstra, and A. C. M. Van Hooijdonk. 2009. Seasonal variation in the Dutch bovine raw milk composition. J. Dairy Sci. 92:4745-4755.

Ikonen, T., S. Morry, A. M. Tyriseva, O. Routtinen, and M. Ojala. 2004. Genetic and phenotypic correlations between milk coagulation properties, milk production traits, somatic cell count, casein content and pH of milk. J. Dairy Sci. 87:458-467.

Jabed, A., S. Wagner, J. McCracken, D. N. Wells, and G. Laible. 2012. Targeted microRNA expression in dairy cattle directs production of $\beta$-lactoglobulin-free, high-casein milk. Proc. Natl. Acad. Sci. USA 109:16811-16816.

Jenson, R. G. 1995. Handbook of Milk Composition. Academic Press, London, UK.

Lindmark-Mansson, H., R. Fonde, and H. E. Petterson. 2003. Composition of Swedish dairy milk. Int. Dairy J. 13:409-425.

Lönnerdal, B. 2003. Nutritional and physiological significance of human milk proteins. Am. J. Clin. Nutr. 77(Suppl.):1537S-1543S.

McParland, S., G. Banos, B. McCarthy, E. Lewis, M. P. Coffey, B. O'Neill, M. O'Donovan, E. Wall, and D. P. Berry. 2012. Validation of mid-infrared spectrometry in milk for predicting body energy status in Holstein-Friesian cows. J. Dairy Sci. 95:7225-7235.

McParland, S., G. Banos, E. Wall, M. P. Coffey, H. Soyeurt, and D. P. Berry. 2011. The use of mid-infrared spectrometry to predict body energy status of Holstein cow. J. Dairy Sci. 94:3651-3661.

McParland, S., E. Lewis, E. Kennedy, S. G. Moore, B. McCarthy, M. O'Donovan, S. T. Butler, J. E. Prce, and D. P. Berry. 2014. Midinfrared spectroscopy of milk as a predictor of energy intake and efficiency in lactating dairy cows. J. Dairy Sci. 97:5863-5871.

Mounier, J., M. C. Rea, P. M. O'Connor, G. F. Fitzgerald, and T. M. Cogan. 2007. Growth Characteristics of Brevibacterium, Corynebacterium, Microbacterium, and Staphylococcus spp. isolated from surface-ripened cheese. Appl. Environ. Microbiol. 73:7732-7739.

Mounsey, J. S., and B. T. O'Kennedy. 2009. Stability of $\beta$-lactoglobulin/ micellar casein mixtures on heating in simulated milk ultrafiltrate at pH 6.0. Int. J. Dairy Technol. 62:493-499.

Ng-Kwai-Hang, K. F., and S. Kim. 1996. Different amounts of betalactoglobulin $\mathrm{A}$ and $\mathrm{B}$ in milk from heterozygous $\mathrm{AB}$ cows. Int. Dairy J. 6:689-695

Ostersen, S., J. Foldager, and J. E. Hermansen. 1997. Effects of stage of lactation, milk protein genotype and body condition at calving on protein composition and renneting properties of bovine milk. J. Dairy Res. 64:207-219.

Reid, M., M. O’Donovan, C. T. Elliot, J. S. Bailey, C. J. Watson, S. T. J. Lalor, B. Corrigan, M. A. Fenlon, and E. Lewis. 2015. The effect of dietary crude protein and phosphorus on grass-fed dairy cow production, nutrient status and milk heat stability. J. Dairy Sci. 98:517-531.

Roucher, V. F., E. Desnots, C. Nael, A. M. Agnoux, M. C. AlexandreGouabeau, D. Darmaun, and C. Y. Boquien. 2013. Use of UPLCESI-MS/MS to quantitate free amino acid concentrations in microsamples of mammalian milk. SpringerPlus 2:622.

Rutten, M. J. M., H. Bovenhuis, J. M. L. Heck, and J. A. M. van Arendonk. 2011. Predicting bovine milk protein composition based on Fourier transform infrared spectra. J. Dairy Sci. 94:5683-5690.

Rutten, M. J. M., H. Bovenhuis, K. A. Hettinga, H. J. F. Van Vanlenberg, and J. A. M. van Arendonk. 2009. Predicting bovine milk fat composition using infrared spectroscopy based on milk samples collected in winter and summer. J. Dairy Sci. 92:6202-6209.

Sarwar, G., H. G. Botting, T. A. Davis, P. Darling, and P. B. Pencharz. 1998. Free amino acids in milks of human subjects, other primates and non-primates. Br. J. Nutr. 79:129-131.

Singh, H. 2004. Heat stability of milk. Int. J. Dairy Technol. 57:111119 
Soyeurt, H., P. Dardenne, F. Dehareng, G. Lognay, D. Veselko, M. Marlier, C. Bertozzi, P. Mayeres, and N. Gengler. 2006. Estimating fatty acid content in cow milk using mid-infrared spectrometry. J. Dairy Sci. 89:3690-3695.

Soyeurt, H., F. Dehareng, N. Gengler, S. McParland, E. Wall, D. P. Berry, M. Coffey, and P. Dardenne. 2011. Mid-infrared prediction of bovine milk fatty acids across multiple breeds, production systems, and countries. J. Dairy Sci. 94:1657-1667.

Swinehart, D. F. 1962. The Beer-Lambert law. J. Chem. Educ. 39:333.

Vasbinder, A. J., and C. G. De Kruif. 2003. Casein- whey protein interactions in heated milk: The influence of $\mathrm{pH}$. Int. Dairy J. 13:669-677.

Visentin, G., A. McDermott, S. McParland, D. P. Berry, O. A. Kenny, A. Brodkorb, M. A. Fenelon, and M. De Marchi. 2015. Prediction of bovine milk technological traits from mid-infrared spectroscopy analysis in dairy cows. J. Dairy Sci. 98:6620-6629.

Visser, S., C. J. Slangen, and H. S. Rollema. 1991. Phenotyping of bovine milk proteins by reversed-phase high performance liquid chromatography. J. Chromatogr. 548:361-370.

Wedholm, A., L. B. Larsen, H. Lindmark-Mansson, A. H. Karlsson, and A. Andren. 2006. Effect of protein composition on the cheesemaking properties of milk from individual dairy cows. J. Dairy Sci 89:3296-3305.

Williams, P. 2007. Statistical terms for evaluation of accuracy and precision. Pages 5-1-5-17 in Near Infrared Technology-Getting the Best Out of Light, 5.0 ed. PDK Grain, Nanaimo, BC, and Winnipeg, Manitoba, Canada. 